\title{
A Chamisso-díj után, a Chamisso-irodalmon túl
}

\author{
Kortárs német nyelvü irodalom és emlékezetkultúra \\ a migráció kontextusában
}

Arjun Appadurai egyik legtöbbet idézett megállapítása szerint a modern szubjektivitást létrehozó imaginációt a 20. század végén leginkább két új tényező határozza meg: az elektronikus mediáció és a tömeges migráció, vagyis emberek (mint közösségek és befogadók) és képek (illetve közvetített események) megjósolhatatlan, a bizonyosságok kereteit folyamatosan lebontó mozgása és találkozása. ${ }^{1}$ A migráció, a medialitás és az imagináció közötti bonyolult összefüggések vizsgálatának relevanciáját és tendenciáit, melyet a modernség és a globalizáció nemzetközi hírü kutatójának tézise implikál, találóan szemléltethetjük azon irodalomtudományi és emlékezetelméleti megközelítések és fogalmak bemutatásával, amelyek a „bevándorló hátterü” szerzők német nyelvű irodalmára irányulóan, az utóbbi körülbelül három évtizedben alakultak ki és képezték vita tárgyát. Az úgynevezett Chamisso-irodalom kategorizálásának és nyelviségének problematikáját először a németül író, de nem (csupán) német anyanyelvű írókat jutalmazó Adelbert von Chamisso-díj immáron lezárult történetének példáján veszem górcső alá, majd a „migráns irodalom” és a posztmigráns (német) társadalom térbeli és időbeli lokalizálásának struktúráival foglalkozom - elsősorban a múltfeldolgozás és a migráció kérdéseinek összefüggésével, a transznacionális emlékezeti terek konstruálódásának vonatkozásában. Végül ebben a kontextusban vázolom fel a kelet-európai származású író(nő)k műveinek (többek között) emlékezetpolitikai jelentőségét.

Az 1985-ben indított és 2017 márciusában utoljára kiosztott Adelbert von Chamisso-díj története szinte szeizmografikus pontossággal tükrözi a kollektív emlékezet (a német emlékezeti kultúra) és az irodalom kapcsolatát problematizáló kutatás dilemmáit, így például a megkülönböztetés és összekötés dialektikájának, valamint a kettősség és a köztesség retorikájának kezdettől fogva ambivalens szerepét a

\footnotetext{
${ }^{1}$ „[A]z elektronikus közvetítettség (mediation) és a tömeges migráció a jelen világot nem mint technikailag új erők jellemzik, hanem mint olyanok, melyek úgy tünik [...] az imagináció munkáját ösztönzik. Együttesen speciális rendellenességeket hoznak létre, mivel mind a nézők, mind a képek (images) egyidejüleg cirkulálnak. Sem a képek, sem a nézők nem illeszkednek be olyan körökbe vagy közönségekbe, melyek lokális, nemzeti vagy regionális tereken belül rögzíthetőek [...]. [a] személyek és a képek is gyakran megjósolhatatlanul találkoznak, az otthon bizonyosságain túl és a helyi és nemzeti médiahatások karanténján kívül. Ez a mobilis és elöreláthatatlan viszony, mely a migratórikus közönségek és a tömegmédiában közvetített események között áll fenn, a modernség és a globalizáció kapcsolatának lényegi meghatározója." Arjun Appadurai, Modernity at Large: Cultural Dimensions of Globalization, Minneapolis, University of Minnesota Press, 1996, 4. (Amennyiben külön nem jelzem, az idegen nyelvü idézeteket a saját fordításomban közlöm. - P. E.)
} 
„bevándorló-irodalom” pozicionálásában, illetve magának a „Chamisso-irodalom” kategorizálásának és kanonizációjának hasonlóan ellentmondásos jellegét. Az évenkénti díjkiosztás kapcsán, vagy a díjazott szerzők nyilatkozataiban folyamatosan felmerült például az a kérdés, hogy tulajdoníthatunk-e bármilyen (akárcsak közvetett) szerepet a szerző életrajzának (származásának, anyanyelvének) a müvek esztétikai minőségének megítélésekor. A kérdés végső soron olyan dichotomizáló határvonások müködésére irányul, mint a saját (német) és az idegen (bevándorolt), a nemzeti irodalom és a „migrációs irodalom” közötti megkülönböztetés, melyet egyfelől a hierarchikus oppozíciókat megkérdőjelező posztstrukturalista elméletek és általában az érintett szerzők is elutasítanak. ${ }^{2}$ Másfelől ebben az esetben paradox módon a differenciálás aktusának szerves része magának a határvonásnak a problematizálása is, úgy, hogy a megkülönböztetést végeredményben annak feloldhatósága konstruálja. Megfigyelhető ez az ambivalencia már a Chamisso-díj alapításának legelején, a kitüntetés létrehozását kezdeményező romanista és filológus Harald Weinrich 1983-as paradigmateremtő előadásában is. ${ }^{3}$ Weinrich éppen abban az évben érvelt egy „kívülről jövő német irodalom" szükségessége mellett, amikor Helmuth Kohl kancellár megállapította, hogy Németország nem a bevándorlók országa (Einwanderungsland). ${ }^{4}$ Weinrich Max Frisch szállóigévé vált kijelentését idézi, miszerint munkaerőket hívtak, de emberek érkeztek, majd ennek megfelelően azt a tézist állítja fel a „multinacionális” és „multikulturálisan sokszínü” Németországban született „külföldiek irodalmáról" (Ausländerliteratur), hogy az valójában "belső lényegét tekintve [...] német” irodalom. Weinrich mindezt a nyelvi és politikai határvonás, az állampolgárság és a nyelvhasználat (anyanyelv) között megszünő egybeesés, illetve a német és a külföldi, a belső és a külső közötti megkülönböztetés feloldhatóságának érvével támasztja alá:

A mai világban a német irodalom már nem lehet csupán azoknak az ügye, akik egy német nyelvü ország állampolgárai. Ahogyan a britek büszkeséggel

\footnotetext{
${ }^{2}$ Catalin Dorian Florescu temesvári születésű svájci író a „migrációs irodalom” kifejezés vonatkozásában „szeretetteljes” és „gyengéd” kirekesztésről beszél, mely a bevándorló szerzők irodalmát „az adott nemzeti irodalom peremére szorítja”. Bettina Spoerri, Auszug aus dem Interview mit Catalin Dorian Florescu und Christina Viragh = Diskurse in die Weite: Kosmopolitische Räume in den Literaturen der Schweiz, hg. Martina Kaмm et al., Zürich, Seismo, 2010, 167, idézi Wiebke Sievers, Zwischen Ausgrenzung und kreativem Potenzial: Migration und Integration in der Literaturwissenschaft = Migrations- und Integrationsforschung: multidisziplinäre Perspektiven, hg. Heinz Fassmann, Julia Dahlvik, Göttingen, Vienna University Press bei V\&R unipress, 2012, 216.

${ }^{3}$ Harald Weinrich, Um eine deutsche Literatur von außen bittend, Chamisso, Nr. 16, 2017, 40-47. (eredeti megjelenés: Merkur, 1983/37, 911-920.)

${ }^{4}$ „A Német Szövetségi Köztársaság nem bevándorló-ország (Einwanderungsland), még akkor sem, ha a nálunk élő külföldiek nagy része tartósan az országban fog maradni." Helmuth KoHL, Rede vor dem deutschen Städtetag in Frankfurt, 14. Juni 1983. http://www.helmut-kohl.de/ index.php?menu_sel=17\&menu_ sel2=\&menu_sel3=\&menu_sel4=\&msg=2272 (Letöltés ideje: 2018. február 1.). A kijelentést megismétli a CDU/CSU és az FDP 1983-as koalíciós egyezménye is.

${ }^{5}$ WeINRICH, i. m., 45. (kiemelés tőlem)
} 
tekintenek a commonwealth-irodalmukra, és ahogyan a franciák magától értetődően saját irodalmukhoz sorolják az egész frankofón irodalmat, úgy nekünk, kevésbé világlátott németeknek is minden okunk megvan arra, hogy egyszer s mindenkorra eltávolodjunk a nemzetállami értelemben vett nemzeti irodalom koncepciójától. Németország egy nyelvből és egy történelemből álló ország, s minden olyan ember, aki úgy használja a német nyelvet, hogy továbbírja ezt a történelmet, természetes honfitársunk, akár belülről jön, akár kívülről. ${ }^{6}$

Weinrich a kortárs bevándorló hátterű irodalmak kapcsán voltaképpen ugyanúgy németként kanonizált, de nyelv- és kultúraváltó szerzőkre (Chamissóra és Canettire ${ }^{7}$ ), illetve elismert francia és brit diszciplináris modellekre hivatkozva kérdőjelezi meg a nemzeti irodalom koncepcióját: ugyanúgy, mint azok a későbbi elméletek, amelyek a német nyelvű irodalmak transznacionális beágyazottságát többek között posztkoloniális elméleti szemszögből vizsgálják, sőt germanisztika helyett kozmopolita germanofóniáról beszélnek. ${ }^{8}$ Hasonló a helyzet a saját és idegen oppozíciójában rejlő kizáró megkülönböztetéssel, melyet Weinrich nem egyfajta nyelvi vagy nemzeti hovatartozások között betöltött köztes pozíció elemzési kategóriájaként használ, hanem Sklovszkijra hivatkozva a nyelven belülre helyez, és az esztétikai tapasztalat konstitutív mozzanataként, az irodalmiság kritériumaként értelmez:

Mert az a távolság vagy idegenség, amit a külföldi tapasztal, még akkor is, ha már nagyon jól tudja a német nyelvet, korántsem rossz tanácsadó esztétikai dolgokban. Emlékezzünk rá, hogy az orosz formalisták [...] csak abban az esetben voltak hajlandóak költészetről beszélni, ha az irodalmi szöveg nyelve

\footnotetext{
${ }^{6}$ Uo., 47.

${ }^{7}$ Vö. Harald Weinrich alábbi szavait: a „kívülről jövő német szerzők az eleve német (binnendeutsch) származású írókhoz hasonlóan a német nyelv mesterei és a jó német nyelvhasználat példaképei lehetnek. Hiszen a német kortárs irodalom szerzői közül ugyan ki írna tisztább németséggel, mint az az Elias Canetti, aki a németet nyolcévesen, harmadik nyelvként sajátította el." WeINRICH, i. m., 47. Weinrich Chamissót „két nyelv és két kultúra” (uo., 40) között helyezi el, Thomas Mannra hivatkozva: „Thomas Mann, aki nagyon közelállónak érezte magát ehhez a német nyelvü francia szerzőhöz [Adelbert von Chamissóhoz], ezt írta: Ismert, hogy alkotás közben gondolatait mindvégig hangosan, franciául mondogatta maga elé, mielőtt versekbe öntötte volna őket - s mégis a végeredmény német mesterköltészet lett. Ez megdöbbentő, sőt mi több, hallatlan" (uo.).

${ }^{8}$ Kosmopolitische „Germanophonie”: Postnationale Perspektiven in der deutschsprachigen Gegenwartsliteratur, hg. Christine Meyer, Würzburg, Königshausen \& Neumann, 2012; Von der nationalen zur internationalen Literatur: Transkulturelle deutschsprachige Literatur und Kultur im Zeitalter globaler Migration, hg. Helmut Sснмiтz, Amsterdam - New York, Rodopi, 2009; Immacolata Amodeo, „Die Heimat heisst Babylon”: Zur Literatur ausländischer Autoren in der Bundesrepublik Deutschland, Opladen, Westdeutscher Verlag, 1996. Christine Meyer „kozmopolita germanofónia”-fogalmához, illetve általában a kortárs német irodalom és migráció kapcsolatához lásd Tномка Beáta, Germanofónia és posztmigráns irodalom, Helikon, 2014/4, 577-592.
} 
úgy van megalkotva, hogy az olvasó figyelmét legalább nyomokban a szavakra irányítja, és megakadályozza, hogy túl gyorsan elérjen a dolgokhoz. [...] Sok jele van tehát annak, hogy azokat a külföldieket, akik nem anyanyelvükön, hanem németül írnak, éppen az idegen nyelv [...] okozta akadályoztatásuk ösztönzi arra, hogy a többieknél sokkal inkább törődjenek a nyelvvel [...], és pontosabban figyeljenek a szavakra s jelentésükre. A nyelv ekkor az idegenség eme leredukálhatatlanságával önmagára hívja fel a figyelmet. ${ }^{9}$

A nem-német anyanyelvü szerzők német nyelvű irodalma az érvelés ezen pontján gyakorlatilag elveszíti „kivétel” jellegét és normává, sőt „modellé” válik, hiszen felszínre hozza az idegenség (elidegenítés) irodalmilag konstitutív funkcióját, illetve nyílttá teszi a „német nemzeti irodalom” és a „migrációs irodalom” közötti differenciálás tarthatatlanságát. A 2008-ban Chamisso-díjjal kitüntetett (bosznia-hercegovinai származású) Saša Stanišić később hasonló módon hangsúlyozta magának az írásnak az általános idegenségét és a többnyelvűség toposzának marginalizáló, diszkriminatív jellegét a bevándorló szerzők irodalmával kapcsolatos mítoszokat leleplező írásában:

Számomra maga az írás egy idegen nyelv. [...] Nagy gyanakvással szemlélem, amikor egy szöveg irodalmi minőségét annak alapján ítéli meg kedvezőbben a kritika, hogy a szerző a második vagy harmadik nyelvén ír, még akkor is, ha kiemelik a nyelvi szerkezetek „szokatlan” használatát, a „különleges” figurákat és a „gazdag” szókincset. Amikor elismerik egy migráns szerző minden egyes apró nyelvi játékát, amivel próbálkozik, az (kis túlzással) csupán egy másik mód arra, hogy azt mondjuk, „nézzétek, milyen jól megtanult ez a külföldi németül”. [...] Hazai szerzők számára sem tilos s nem lehetetlen kísérletezni a nyelvvel [...]. A nyelv az egyetlen olyan ország, amelynek nincsenek határai. ${ }^{10}$

Weinrich alapító szövegében a „kívülről jövő német irodalom” megközelítésének problematikáját az 1980-as évek társadalmi és politikai eseményeivel összefüggésben vizsgálja: utal a vendégmunkások fogadtatására az irodalmi életben (például a PoLiKunst, vagyis Polynationaler Literatur- und Kunstverein für GastarbeiterSchriftsteller nevü érdekképviseleti szervezet 1980 -as alapítására ${ }^{11}$ ), akárcsak az idegengyülölő lózungok („Ausländer raus”) terjedésére. A díj 2017-es megszüntetése ellen tiltakozók hasonlóan az európai migrációs válságra hivatkozva kérdőjelezték

\footnotetext{
${ }^{9}$ WEINRICH, i. m., 45.

${ }^{10}$ Saša Stanišić, Three Myths of Immigrant Writing: A View from Germany, 2008.

http://wordswithoutborders.org/article/three-myths-of-immigrant-writing-a-view-from-germany (Letöltés ideje: 2018. február 1.)

${ }^{11}$ WeInRICH, i. m., 43.
} 
meg a döntést, ${ }^{12}$ akárcsak az elismerést dotáló Robert Bosch Alapítvány képviselői. Uta-Micaela Dürig elnök szerint a kitüntetés adományozását épp azért kell leállítani, mert elérte célját, feleslegessé vált, mivel a Chamisso-szerzők a német irodalom magától értetődő részévé váltak:

A kulturális sokszínűség társadalmunkban s a német nyelvü irodalomban is időközben széleskörüen a normalitás részévé vált. Ezért nézőpontunk szerint egy díj feladata nem az, hogy kiemelje a szerzők biografikus származását és tapasztalatát, hanem hogy támogassa a társadalomban az együttélést és az összetartozás érzését. Annál is inkább így van ez, mivel sok migráns hátterű szerző immáron a második generáció óta él Németországban. A német nyelvvel nőttek fel, s német nyelvű szerzőként tekintenek magukra. Műveik a kortárs német irodalom magától értetődő és nélkülözhetetlen elemei. S a Chamisso-díjasok is elnyernek más fontos irodalmi kitüntetéseket is, mint például a Német Könyvdijat. ${ }^{13}$

A „német” és a „bevándorló” szerzők közötti különbség, illetve magának a distinkciónak a megszűnése - a Chamisso-díj „célja” - viszont egyben a Chamisso-díj kiindulópontjaként, elméleti legitimációjaként is szolgált. Harald Weinrich már a kitüntetés kezdeményezésekor arról beszélt, hogy a „kívülről jövő német szerzők [...] az eleve német [binnendeutsch] írókhoz hasonlóan a német nyelv mesterei lehetnek”, illetve „a külföldiek [...] jobb németséggel írnak és beszélnek, mint egyes németek”. ${ }^{14} \mathrm{~A}$ „nemnémet származásư" szerzők megkülönböztetésének és támogatásának exklúziós aktusa ebben az ellentmondásos konstellációban vált a Chamisso-irodalom kanonizálásának inklúziós stratégiájává.

Hasonló paradoxonok fémjelzik a Chamisso-díj átadásának teljes történetét. A kitüntethetőség elsődleges kritériumaként eredetileg pusztán az írók származása szerepelt, amit 2012-ben módosítottak: innentől fogva az elismerés célközönségét olyan

\footnotetext{
${ }^{12}$ Lásd Iris Radisch ironikus szavait a tiltakozásról: „[r] osszul választották meg [szerintük] a Chamisso-díj leállításának időpontját. Pont most, miután először a németül író vendégmunkásgyerekek, azután a keleteurópai számüzöttek, a jugoszláv háborús menekültek, a kései hazatelepülők (Spätaussiedler) és a világ minden tájékáról érkező menedékkérők megkapták a támogatást, fontos lenne, hogy rendelkezésre álljon a díj a következő években és évtizedekben várhatóan ránk zúduló, menekülésről és elüzetésről szóló regények számára. Úgy fog hiányozni a díj az író menekülteknek és németül debütálóknak, mint Chamisso elbeszélésében szegény Schlemihlnek az árnyéka." Iris RADisch, Unprämierte Migrantenliteratur, Die Zeit, 2016/40, http://www.zeit.de/2016/40/chamisso-preis-literatur-protest-fluechtlinge (Letöltés ideje: 2018. február 1.). Uta-Micaela Dürig az aktuális társadalmi változásokra és kihívásokra hivatkozva említi meg, hogy a Bosch Alapítvány létrehozott egy menekültügyi szakértői bizottságot, és számos helyi projekttel támogatja a menedékkérők integrációját. Uta-Micaela DüRIG, „Im Fokus wird die Förderung kultureller Teilhabe durch Literaturvermittlung stehen": Rückblick und Ausblick von Uta-Micaela Dürig, Geschäftsführerin der Robert Bosch Stiftung, Chamisso-Magazin Viele Kulturen - eine Sprache, 2017/16, 51-52.

${ }^{13}$ DÜRIG, i. m., 51.

${ }^{14}$ WEINRICH, i. m., 46, 47.
} 
szerzők alkották, akik németül írnak, de művükben meghatározó jelentőséggel bír a „kultúraváltás”. (Így fordulhatott elő például 2016-ban, hogy mindkét Chamissodijazott írónő, Esther Kinsky és Uljana Wolf is „született német” szerző volt.) A díj kiírásának módosítását azzal magyarázták, hogy az érintett szerzők irodalma „a kortárs német irodalom magától értetődő és nélkülözhetetlen alkotóelemévé vált", ${ }^{15}$ tehát ismét a külső és belső dichotómiájának megingása az, ami a kitüntetést - „feleslegessége" ellenére, vagy éppen ezáltal - megindokolta.

Ahogyan a Chamisso-díj definíciójának módosítása is jelzi, az elismerés kezdettől fogva kritikát generált, és vitatott funkciókat töltött be. Az immanensen irodalmi és nem-irodalmi szempontok keveredése körül kialakult diszkusszión túl jellemző az az ellentmondás, hogy míg a kitüntetés egyfelől közismert és hatékony kanonizáló instanciaként müködött - mint egyfajta „belépőjegy az irodalmi életbe” 16 - addig mind a szerzőket, mind a kritikát aggályokkal töltötte el a diszkrimináló „külföldi szerző” címke, a díj általi „beskatulyázás” („Nischenpreis” ${ }^{17}$ ) lehetősége, az irodalmi „rezervátum” létrehozásának ${ }^{18}$ veszélye. A Chamisso-díj (és létjogosultságának) bírálata így elkerülhetetlenül beépült az olyan tudományos rendezvények által elevenen tartott hagyományba, mint a kitüntetés 25. évfordulójának alkalmából Marbachban megrendezett szimpózium (Chamisso - wohin? Über die deutschsprachige Literatur von Autoren aus aller Welt), vagy a Chamisso-irodalom kapcsán az interkulturalitás-kutatást tematizáló 2014-es müncheni tanácskozás (Chamisso-Literatur - eine "Nomadisierung der Moderne“? Interdisziplinäre Perspektiven der Interkulturalitätsforschung).

A tudományos reflexióban, a laudációkban, a kitüntetettek írásaiban gyakorlatilag állandó toposszá vált (illetve ahogyan láthattuk, kezdettől fogva jelen volt) a többnyelvűség vagy nyelvi idegenség általánosságának hangsúlyozása, illetve a normaként

\footnotetext{
${ }^{15}$ Az 1985-ös eredeti felhívás szövege a Bosch Alapítvány honlapján olvasható, eszerint a kitüntetés „nem-német anyanyelvü, németül író” szerzőknek szól - ezt módosították később „németül író” szerzőkre, akiknek a „művészetét a kultúraváltás határozza meg”: „A társadalmi realitás ma az, hogy a migrációs hátterű szerzők folyamatosan növekvő csoportja magától értetődő anyanyelveként beszéli a németet. Ezen szerzők irodalmát ugyan tematikájában és stilisztikailag meghatározza a nyelv és a kultúraváltás, de magától értetődő és nélkülözhetetlen részévé vált a kortárs német irodalomnak." http:// projects.bosch-stiftung.de/content_projekte/language1/html/14169.asp (Letöltés ideje: 2018. február 1.) ${ }^{16}$ Irmgard Ackermann, Der Chamisso-Preis und der Literaturkanon = Die andere deutsche Literatur: Istanbuler Vorträge, hg. Manfred DurzaK et al., Würzburg, Königshausen \& Neumann, 2004, 47-51. A Chamisso-irodalom és a biografikus diskurzus problematikájához, illetve a „biografika transznacionális megközelítéséhez" lásd Hannes Schweiger, Transnationale Lebensgeschichten: Der biographische Diskurs über die Literatur eingewanderter AutorInnen, Aussiger Beiträge (National - postnational - transnational? Neuere Perspektiven auf die deutschsprachige Gegenwartsliteratur aus Mittel- und Osteuropa), 2012/ 6, 13-31.

${ }^{17}$ René Kegelmann, Türöffner oder Etikettierung? Der Adelbert-von-Chamisso-Preis und dessen Wirkung in der Öffentlichkeit = Die Kunst geht auch nach Brot! Wahrnehmung und Wertschätzung von Literatur, hg. Sylvie Grimm-Hamen, Françoise Willmann, Berlin, Frank \& Timme, 2010, 13-28.

${ }^{18}$ Michael Hofmann, Interkulturelle Literaturwissenschaft: Eine Einführung, Paderborn, W. Fink, 2006, 320.
} 
tételezett „német” irodalom és az attól eltérő „migráns” irodalom kettősségének elutasítása. Találóan illusztrálják ezt a nemzetközileg elismert bolgár származású német szerző, Ilija Trojanow Migráció mint haza címü beszédének sokat idézett szavai: „Chamisso-irodalom nincsen többé, csupán csak a német nyelvű irodalom belenövése a világirodalmiságba (Weltliterarische), a világlátottság (Weltläufigkeit) és a többnyelvűség ügyvivőinek közremüködésével". ${ }^{19}$ A Chamisso-irodalmat övező élénk diszkussziókat az 1980-as évektől napjainkig tehát ironikus módon, a tagadás általi megerősítés (assertion in denial ${ }^{20}$ ) toposzával megragadható, problematikusként továbbírt fogalmak és differenciák határozzák meg.

A továbbiakban a Chamisso-díjátadás kapcsán felmerülő kettősségeket, illetve fogalmiságot a migráció és az irodalom kapcsolatára és a bevándorlás kontextusában változó (posztmigráns) német emlékezeti kultúrára irányuló elméleti pozíciók összefüggéseivel kapcsolatban vizsgálom.

\section{Külföldiek - hídverök - nyelvvált(oztat)ók: a Chamisso-irodalom nyelve és helye}

Ahogyan láthattuk, a németül író, de nem német származású szerzők irodalmából elsősorban a nyelviségre való hivatkozás által vált konstruálhatóvá egy olyan szövegkorpusz, amellyel szemben a legkevésbé merülhet fel az a vád, hogy alapjában véve kizáró kritériumok (egzotizáló, marginalizáló, illetve irodalmon kívüli - például biografikus - szempontok) érvényesítésén alapul. A nyelviség aspektusát a Chamisso-díj már tárgyalt, 2012-es módosítása is hangsúlyozza, amikor olyan „kiemelkedő, németül író szerzőket” definiál célcsoportként, „akiknek a művében meghatározó szerepet kap a kultúraváltás, és akiket a nyelvvel való rendhagyó, a német irodalmat gazdagító bánásmód egyesít". ${ }^{21}$ Mégis éppen a nyelviség problematizálásának kapcsán ütközünk ismét

\footnotetext{
${ }_{19}$ Ilija Trojanow, Migration als Heimat: Von den literarischen Früchten der Entwurzelung und den Agenten der Mehrsprachigkeit, 2009. http://www.nzz.ch/aktuell/feuilleton/uebersicht/migration-alsheimat-1.4081973 (Letöltés ideje: 2018. február 1.)

${ }^{20}$ Hasonló folyamatok figyelhetőek meg a svájci irodalom fogalmának létjogosultságára irányuló tudományos diszkusszióban, melyet sokak szerint éppen a vita tárgyának kétségessége, sőt egyenesen tagadása éltet. Michael Böhler a self-assertion in denial (Terry Eagelton) paradoxonát a svájci nemzetépítés egészére találónak tartja, tekintettel annak eleve ambivalens (a nyelvi és a politikai határok különbözőségére épülö) konstellációjára. Michael BöHLER, Gefängnis Schweiz oder Bergnebel Seldwyla? Zur Frage von Raum- und Zeitbindung der Schweizer Literatur = Schweiz Schreiben. Zur Konstruktion und Dekonstruktion des Mythos Schweiz in der Gegenwartsliteratur, hg. Jürgen BARKhoff, Valerie HefFernan, Berlin - New York, De Gruyter, 2010, 47.

${ }^{21}$ A bevándorló szerzők többnyelvüségéhez és a Chamisso-irodalom polifóniájához lásd az alábbi munkákat: Bettina SPOERRI, „stifmuter” und „galtbir”: Literarische Kreation auf der Schnittstelle von Sprachen = Diskurse in die Weite, i. m., 126-139; Claudia TATASCIORE, Sprache als Ausweg, Sprache als Stigma: Eine Reflexion über die Mehrsprachigkeit in den Texten von Terézia Mora, Aussiger Beiträge, 2012/6, 219-236; Margrit Zinggeler, Migration and the Transformation of German Swiss Literature = M. Z., How Second Generation Immigrants Writers Have Transformed Swiss and German Language Literature: A Study of
} 
ellentmondásokba, hiszen az érintett szerzők pontosan műveik nyelvi-esztétikai minőségének alapján tekintik magukat a német irodalom részének, illetve lépik át a „német” és a német irodalmat "gazdagító" irodalom között megvont határvonalat. Terézia Mora például arra a felvetésre, hogy „mégsem olyan értelemben vett német szerző [...], mint Goethe vagy Thomas Mann", azzal válaszolt, hogy ugyanannyira német, mint Kafka, ${ }^{22}$ $s$ egyben visszautasította a szintén konvencióvá vált megkülönböztetést anyanyelv és idegen nyelv, illetve magyarországi „otthonosság” és Németországban érzett „idegenség” között. („Nincsenek idegenség-érzéseim itt. Idegen a magyar faluban voltam. Nem váltottam nyelvet. A német és a magyar mindkettő az anyanyelvem." ${ }^{23}$ ) Hasonlóan érvel Ilija Trojanow, amikor Kafka, Celan és Joseph Conrad mellett a német nyelvü Nobel-díjasok (Canetti, Grass, Jelinek és Herta Müller) kánonjára hivatkozva azt állapítja meg, hogy az olyan kortárs szerzők, mint Yoko Tawada, Emine Sevgi Özdamar, Feridun Zaimoglu vagy Ilma Rakusa semmiképp sem felelnek meg annak a régi elképzelésnek, miszerint a Chamisso-irodalom sajátos, újszerü és különleges lenne:

A német nyelvü irodalomban is kozmopolita sokszínüség uralkodik, szerzői vándorló „sorstalanok” [...]. Különben mi mással magyarázhatnánk azt, hogy az utolsó négy német nyelvü Nobel-díjas minden volt, csak nem tipikus német: a Bulgáriában született szefárd Elias Canettitől kezdve - aki csak harmadik nyelvként tanulta meg a németet -, a danzigi Günter Grasson át - akinek anyja kasub származású volt - , illetve az osztrák Jelineken át apja cseh zsidó volt - , egészen a bánáti sváb Herta Müllerig. Két szó szerinti migráns, s mind a négy multi-, inter- és transzkulturális utakon jár. ${ }^{24}$

A nyelv „gazdagító”, kísérletező kezelése Saša Stanišić szerint is csak egyike a bevándorló szerzők irodalmával kapcsolatos beszűkítő és téves elvárásoknak, mint amilyen a migrációs tapasztalat (önéletrajzi alapú) tematizálásának a mítosza. Stanišić ezen a ponton - mint már elhangzott - az irodalmi nyelv általános (az anyanyelvi írásra is jellemző) idegenségére hivatkozik („Maga az írás idegen nyelv”), ${ }^{25}$ illetve a migráció

Sensorial Narratives by Authors Writing from the Swiss'Secondo-Space', Lewiston, The Edwin Mellen Press, 2011, 89-110; Bianka BuRKa, Manifestationen der Mehrsprachigkeit und Ausdrucksformen des „Fremden” in deutschsprachigen literarischen Texten: Exemplifiziert am Beispiel von Terézia Moras Texten, Tübingen, Narr Francke Attempto Verlag, 2016. - Az irodalmi többnyelvüség tipológiájához lásd Monika ScHмITzEmans, Literatur und Vielsprachigkeit: Aspekte, Themen, Voraussetzungen = Literatur und Vielsprachigkeit: Aspekte, Themen, Voraussetzungen, hg. Monika Schmitz-Emans, Heidelberg, Synchron, 2004, 11-26.

${ }^{22}$ Terézia MoRA et al., „Ich bin ein Teil der deutschen Literatur, so deutsch wie Kafka“: Interview mit Terézia Mora, Imran Ayata, Wladimir Kaminer und Navid Kermani, Literaturen, 2005/4, 28.

${ }^{23}$ Uo.- A nyelvmegtartás és a nyelvváltás problematikájához lásd TномкA, i. m.

${ }^{24}$ Trojanow, $i . m$.

${ }^{25}$ Stanišić azt is kiemeli, hogy „a migráns szerzők már nem marginális jelenségek, hanem szinte mainstream tulajdonságokkal bíró, jelentős vonatkoztatási pontok [...]. A migráns irodalmak nem szigetet képeznek a nemzeti irodalom tengerében, hanem annak integráns részei [...]”. STANišić, i. m. 
általánossá vált tapasztalata kapcsán kiemeli a centrum és periféria közötti ellentmondás (valamint a nemzeti irodalmi kánon és a migráns irodalom közötti határvonás) megszűnését. Alapjában véve ezeken a homogenizáló elválasztásokon alapulnak ugyanis azok a tarthatatlannak bizonyuló tézisek is, miszerint a „migráns irodalom” gazdagítja a német nyelvet és kultúrát, illetve - az a szintén politikailag korrektnek szánt és elterjedt vélemény -, hogy az ún. „Chamisso-szerzők” a tolmácséhoz hasonló küldetésü közvetítők a „saját” és a német kultúra között.

Az elválasztott világok közötti köztesség pozíciójából történő közvetítést bár gyakran tekintik a kitüntetett szerzők „küldetésének“ ${ }^{26}$ mégis általános elutasítás övezi az írók részéről és az elméleti megközelítésekben is. Beszédes címe van például Yoko Tawada szövegének: Nem akartam hidat verni, ${ }^{27}$ vagy Güney Dal írásának: Nem vagyok híd ${ }^{28} \mathrm{~s}$ ugyanerre vonatkozik az olaszországi születésü német író, Franco Biondi megállapítása, miszerint nem az olasz és német kultúrák között, hanem a német és az olasz kultúrával él. ${ }^{29} \mathrm{~A}$ köztesség és közvetítés kézenfekvőnek tűnő, de hierarchikus oppozíciókra épülő, az aszimmetrikus hatalmi viszonyokat figyelmen kívül hagyó kategóriáit hasonló elutasítás övezi az irodalomtudományi reflexió terén is. Programadó ebből a szempontból Leslie A. Adelson amerikai germanista és irodalomtörténész Against Between - Ein Manifest gegen das Dazwischen (A között ellen - kiáltvány a köztesség ellen) címü munkája. Adelson tiltakozik a migráns irodalmi szereplők köztes terekben történő, polarizáló pozicionálása ellen, amely nem veszi figyelembe a kultúrák és irodalmak hálózatszerü összefonódásait, interakciókra való nyitottságukat:

A Németországba irányuló tömeges migrációt [...] és a „migránsok irodalmát” vagy a „németországi interkulturális irodalmat” (Chiellino 2000) tematizáló élénk diszkusszióban a törökök központi reprezentatív pozíciót töltenek be [...], egy „két világ közötti” mozdulatlan hídon. E két világ egyike hagyományosan európainak feltételezett, a másik pedig nem, amíg a kettejük közötti tér pedig vagy diszkriminatórikus kizárások helyszíneként,

\footnotetext{
${ }^{26}$ Sigrid Löffler a Chamisso-díjjal kitüntetett Terézia Mora laudációjában például azt emeli ki, hogy a „fordítások Európájában [...] az írók tolmácsként működnek, nem csupán azáltal, hogy leírják [...] a kultúrákat, hanem azáltal is, hogy kultúrájukat másoknak közvetítik, számukra lefordítják". Sigrid LöFFLER, Laudatio von Sigrid Löffler auf Terézia Mora, 2010. http://projects.bosch-stiftung.de/content_projekte/ language1/downloads/PM_100304_Chamisso_Preis_Laudationes.pdf (Letöltés ideje: 2018. február 1.) ${ }_{27}$ Yoko TAWADA, Ich wollte keine Brücke schlagen = Aber die Mandarinen müssen heute abend noch geraubt werden, Tübingen, Konkursbuch Verlag Claudia Gehrke, 1997, 65-72.

${ }^{28}$ Güney DAL, Ich bin keine Brücke, Der Tagesspiegel, 2000. május 19.

${ }^{29}$ Idézi Katrin Hillgruber, Die Sprachwanderer, Potsdamer Neueste Nachrichten, 2009. december 1. A fenti értelemben vett köztesség problematikájához lásd Sandra Vlasta, Das Ende des 'Dazwischen': Ausbildung von Identitäten in Texten von Imran Ayata, Yadé Kara und Feridan Zaimoğlu = Von der nationalen zur internationalen Literatur, i. m., 101-196; Jim JoRdAN, More Than A Metaphor: The Passing of The Two Worlds Paradigm in German-Language Diasporic Literature, German Life and Letters, 2006/4, 488-499; Moray McGowan, Brücken und Brücken-Köpfe: Wandlungen einer Metapher in der türkisch-deutschen Literatur = Die andere deutsche Literatur, i. m., 31-40.
} 
vagy egy boldog hibriditás hazájaként jelenítődik meg. [...] A törökök a németországi bevándorlók képzeletbeli hídjával a legnagyobb terhet vették magukra, hiszen kiváltják a „civilizációk ütközésének” (Huntington) félelmeit vagy pedig fellobbantják a „kultúrák dialógusának” reményét. A két, eredetinek és kölcsönösen kizárónak vélt világ szembeállításának retorikája jól ismert. A „közöttük” lévő tér gyakran olyan migránsoké, akiket hajthatatlanul egy sehová nem vezető hídra száműztek. ${ }^{30}$

A köztesség „kulturális fabulája” (cultural fable), illetve annak a fordítás, közvetítés általi meghaladása helyett Adelson a migrációs történetek kapcsán inkább összefonódó narratívákról, érintkező történetekről (touching tales) beszél - így válnak számára fogalmilag megragadhatóvá és értelmezhetővé a történelmi múlt és a jelen (például a német, a török és a zsidó történelem) elbeszéléseinek kölcsönhatásai. ${ }^{31}$

Az egyik pontból a másikba migrálás, illetve a kettő köztességében oszcillálás és ebből eredően a két nyelv és kultúra közötti „gazdagító” közvetítés említett mozzanatai mellett a megérkezés aktusára is egyformán hivatkoznak mind az írók, mind a Chamisso-irodalomra épülő értelmezői diskurzusok. A megérkezés - az idegenséghez hasonlóan - ebben az értelemben nem elsősorban egy migrációs tapasztalat függvénye (nem csupán a bevándorlás célját vagy végpontját jelenti), hanem az esztétikai tevékenység következménye. Mora például arról beszél, hogy az íráson keresztül érkezett meg a világba; ${ }^{32}$ egy 2008-as tanulmánykötet címében is kiemeli a Chamissoirodalom vonatkozásában a nyelvbe való beköltözés és az irodalomba történő megérkezés fontosságát ${ }^{33}$ a Bosch Alapítvány pedig azzal indokolta a díj megszüntetését, hogy a migráns hátterü szerzők „megérkeztek a német irodalmi életbe”. ${ }^{34}$ A megérkezés retorikája hatékonyan ellenpontozza a migráns irodalomnak a köztesség pozíciójára történő redukálását, valamint a „kétféle” irodalom (nyelv, kultúra) kapcsolatának a közvetítés - fordítás - nyelvi gazdagítás említett kategóriáival történő leírását (sőt magát a „német irodalom” és „migrációs irodalom”, a „haza” és a „célország” közötti dichotomizáló határvonást is). Ugyanez vonatkozik a köztes tér ellentétes előjelü értelmezésére a posztstrukturalista, posztkoloniális elméletekben, melyek az említett

\footnotetext{
${ }^{30}$ Leslie A. Adelson, The Turkish Turn in Contemporary German Literature: Toward a New Critical Grammar of Migration, New York, Palgrave Macmillan, 2005, 5-6.

${ }^{31}$ Leslie A. Adelson, Touching Tales of Turks, Germans, and Jews: Cultural Alterity, Historical Narrative, and Literary Riddles for the 1990s, New German Critique, 2000/80, 93-124.

${ }^{32}$ Terézia MorA, „Ich bin durschs Schreiben im Leben angekommen“: Terézia Mora im Gespräch; Interview von Thomas Köster mit Terézia Mora, 2010. http://www.goethe.de/ins/it/lp/prj/lit/bue/gelit/de6062887. htm (Letöltés ideje: 2018. február 1.)

${ }^{33}$ Eingezogen in die Sprache, angekommen in der Literatur: Positionen des Schreibens in unserem Einwanderungsland, hg. Uwe PörKsEN, Bernd BusCH, Göttingen, Wallstein, 2008.

${ }^{34}$ Robert Bosch Stiftung: Ziel erreicht. Robert Bosch Stiftung beendet Chamisso-Preis, Stuttgart, 2016. http:// www.bosch-stiftung.de/de/presse/2016/09/ziel-erreicht-robert-bosch-stiftung-beendet-chamisso-preis (Letöltés ideje: 2018. február 1.)
} 
külső-belső differenciák közötti határt a nyelven, a kultúrán és a szubjektumon belülre helyezik. ${ }^{35}$

A köztesség (a hibriditáshoz hasonlíthatóan) Homi K. Bhabha ismert értelmezésében egy olyan tranzitorikus vagy köztes tér jellegzetessége, melyben mindenféle „eredeti polaritás” és hierarchia nélkül konstruálódnak identitások és differenciák, s amelynek metaforája a lépcsőház. ${ }^{36} \mathrm{~A}$ migráns írók köztes pozíciója ebben az értelemben a migráns irodalom szubverzív (hibriditást felfedö) potenciálját is garantálja, $s$ mindez átértelmezi a köztesség mellett a fordítás jelentését is. A fordítás a transznacionális migráció kontextusában nem két elhatárolható, szimmetrikus kultúra és nyelv közötti közvetítést jelent (hiszen a Chamisso-irodalom a fenti értelemben éppen a kulturális hasadások és differenciák lefordíthatatlanságát leplezheti le), ${ }^{37}$ hanem sokkal inkább kulturális fordítást: egyfajta létmódot, a „szignifikáció komplex formáját”, a kultúra konstitutív móduszát:

\begin{abstract}
A kultúra [...] egyaránt transznacionális és transzlacionális. [...] A kulturális transzformáció transznacionális dimenziója - a migráció, a diaszpóra, a folyamatos eltolódás (displacement), az újbóli elhelyezés - a kulturális fordítás folyamatát a szignifikáció egy összetett formájává alakítja. Az autentikus „népi” hagyományokon vagy a "nemzethez” és "népekhez” hasonló kulturális különlegességek mélyen berögzült mítoszain nyugvó, természetes vagy naturalizált, egységteremtő diskurzus nemigen működhet immár vonatkoztatási pontként. Ennek a helyzetnek nagy, bár nyugtalanító előnye abban áll, hogy erősebben ébreszt bennünket annak tudatára, hogy a kultúra konstrukció és a hagyomány kitalálás. ${ }^{38}$
\end{abstract}

A Chamisso-írók ebben az értelemben nem lokalizálhatóak tehát sem a német irodalmon kívül, sem a „német” és „nem (csak) német” irodalom között(i hídon), hanem csakis abban a köztes hibrid térben, melyet Bhabha a lépcsőház metaforájával

\footnotetext{
${ }_{35}$ A kulturális fordítás elméletéhez és fogalmiságához lásd The Trans/National Study of Culture: A Translational Perspective, hg. Doris Bachmann-Medick, Berlin - Boston, de Gruyter, 2014.

${ }^{36}$ Homi K. Bhabha, Die Verortung der Kultur, übers. Michael Schiffmann, Jürgen Freudl, Tübingen, Stauffenburg, 2000, 5. Bhabha a köztest térrel rokon értelmü lépcsőház metaforáját így írja le: „A lépcsőház, mint identitásmeghatározások közötti küszöb-tér a szimbolikus interakció folyamatává válik [...], mely a fent és a lent, a fekete és fehér különbségét konstruálja. A lépcsőház oda-vissza irányultsága, a rá jellemző mozgás és az időbeli átmenet megakadályozza, hogy a felső és az alsó végében identitások rögzüljenek, eredeti polaritásokként. A rögzült identifikációk közötti terek közti átmenet egy kulturális hibriditást tesz lehetővé, melyben a differencia átvett vagy elrendelt hierarchia nélkül kap helyet." BHABHA, Die Verortung, i. m., 5 .

${ }^{37}$ Bhabha szerint az „in-between” migráns kultúrája a „kultúra lefordíthatatlanságának tevékenységét dramatizálja”, vagyis az asszimilációpárti vagy rasszista elképzelések premisszáit meghaladva felmutatja a kulturális differenciával való azonosulás ambivalenciáit, a hasadást és a hibriditást. Homi K. BHABHA, The Location of Culture, London - New York, Routledge, 2004 [1994], 321, idézi Sievers, i. m., 219.

${ }^{38}$ Bнавна, Die Verortung, i. m., 257.
} 
ír le - s ezeket az eltolódásokat szemlélteti a Chamisso-irodalom megnevezéseinek alakulástörténete is.

A homogenizáló-kirekesztő jellegük és nem-esztétikai megalapozottságuk miatt kritizált olyan fogalmakat, mint a „vendégmunkás-irodalom” (Gastarbeiterliteratur), az „érintettség irodalma” (Betroffenheitsliteratur) vagy „külföldiek irodalma” (Ausländerliteratur) eredetileg maguk a bevándorló szerzők (Franco Biondi) javasolták és használták. ${ }^{39}$ Ezeket a kifejezéseket viszonylag gyorsan felváltották olyan megnevezések, mint a "migráns” vagy "migrációs” irodalom (Migrantenliteratur, Migrationsliteratur), melyek már nem szociológiai szempontokat, hanem az irodalom szerzőorientált (biografikus) és tematikus megközelítését érvényesítik. A Chamisso-irodalom olyan új elnevezései, mint a „transzkulturális” vagy „interkulturális”, illetve „posztmigráns irodalom” ${ }^{40}$ pedig már a dichotomizáló, a homogén kulturális terek képzetére és a normatív diskurzusokra épülö kategorizálás elutasítását tükrözik. Fokozatosan elsődleges kutatási szemponttá vált tehát a szövegek nyelvisége, mégpedig nem a már tárgyalt egzotizáló összefüggésben (a német és a „németet gazdagító” irodalmi nyelv vonatkozásában), hanem annak a belátásnak az értelmében, hogy interakciójuk köztes, hibrid terében mind a „német”, mind a „migráns” kultúra és nyelv átalakul. Harald Weinrich szavaival a "Chamisso nevében a nyelvet átalakító" szerzők „maguk is átalakultak (gewandelt) azáltal, hogy egy idegen nyelvbe vándoroltak, s ott a német nyelvet átalakították (ver-wandelt)". ${ }^{41}$

A Chamisso-irodalom nyelviségére, „átalakító” és szubverzív potenciáljára (a hierarchikus oppozíciókkal és hatalmi viszonyokkal való összefonódásaira) fókuszáló megnevezések közül kiemelendőek a kis irodalom és a germanofón irodalom fogalmai. Gilles Deleuze és Félix Guattari ismert munkájában ${ }^{42}$ Kafka egy befejezetlen írásából kiindulva dolgozza ki a kis irodalmak (littérature mineure) koncepcióját, amely - hasonlóan a szintén Deleuze és Guattari által bevezetett fogalmakhoz, a rizómához és a nomádsághoz - újabban kulcsfogalommá vált a bevándorolt szerzők irodalmának

\footnotetext{
${ }^{39}$ Franco Biondi, Rafik Schami, Literatur der Betroffenheit: Bemerkungen zur Gastarbeiterliteratur $=\mathrm{Zu}$ Hause in der Fremde: Ein bundesdeutsches Ausländer-Lesebuch, hg. Christian Schaffernicht, Fischerhude, Verlag Atelier im Bauernhaus, 1981, 124-136. - Franco Biondi „vendégmunkás-irodalom” fogalmához lásd Franco BiONDI, „Literatur ist Gedächtnis“: Interview von Immacolata Amodeo mit Franco Biondi = Dossier Migrationsliteratur - eine neue deutsche Literatur?, Berlin, Heinrich Böll Stiftung, 2009, 9-11; SIEVERs, i. $m$.

${ }^{40} \mathrm{~A}$ fogalmat ebben a kontextusban elöször Shermin Langhoff használta a posztmigráns színház kifejezésben. A posztkolonializmus és a posztmigráció kapcsolatához lásd Nach der Migration: Postmigrantische Perspektiven jenseits der Parallelgesellschaft, hg. Erol Yildiz, Marc Hill, Bielefeld, Transcript, 2015. - Az inter- és transzkulturális irodalomtudomány kategóriáihoz lásd Interkulturelle Literatur in Deutschland: Ein Handbuch, hg. Carmine Chiellino, Stuttgart, Metzler, 2000; Hofmann, i. m.; Von der nationalen zur internationalen Literatur, i. $m$.

${ }^{41}$ WEINRICH, i. m., 21.

${ }^{42}$ Gilles Deleuze, Félix Guattari, Kafka: A kisebbségi irodalomért, ford. Karácsonyi Judit, Bp., Qadmon, 2009.
} 
értelmezésében. ${ }^{43}$ Deleuze és Guattari szerint a "kisebbségi irodalom (littérature mineure) nem egy kisebbségi nyelv irodalma, hanem olyan irodalom, amelyet a kisebbség a többség nyelvén ír” ${ }^{44}$ A kis(ebbségi) „minden olyan irodalom forradalmi feltételeit jelöli, amely a nagynak (vagy intézményesítettnek) nevezett irodalmon belül létezik", ${ }^{45}$ három jellemzője pedig a nyelvi deterritorializáltság, az individuálisnak a közvetlen-politikaira történő rákapcsolódása és a megnyilatkozás kollektív elrendeződése. ${ }^{46}$ Jóllehet a kis(ebbségi) irodalom fogalma újabb külön kategóriát hoz létre a Chamisso-szerzők művei körül kialakult diszkusszióban, azonban éppen olyan szövegeket jellemez, amelyek szemben állnak mindenféle hegemoniális követeléssel, és lebontják a homogenizáló és dichotomizáló elválasztásokon alapuló hierarchiákat (például a nemzeti irodalom és a migrációs irodalom közötti megkülönböztetést) elsősorban poétikai, és nem politikai aktusként.

Hasonló a kiindulópontja azoknak a megközelítéseknek, melyek posztstrukturalista, posztkolonialista elméleti belátásokat vonatkoztatnak a posztmigráns német (nyelvü) irodalomra. ${ }^{47} \mathrm{~A}$ kozmopolita germanofónia például (bár „monokulturális” szerzők szövegeihez is elméleti keretként szolgál) szembehelyezkedik a „kulturalista koncepciók esszencialista előfeltevéseivel", ${ }^{48} \mathrm{~s}$ a postcolonial studies fogalmiságával (writing back, hibriditás) operálva köt össze - Adelsonhoz hasonlóan - aktuális migrációs jelenségeket a (német) történelmi múltfeldolgozás kihívásaival:

Pontosan Németország [...] fejlesztette ki a kolonizáció egy különösen radikális és perverz alfaját, amikor a második világháborúban meghódította és elfoglalta Kelet-Európa kiterjedt területeit, s egyúttal szisztematikusan deportálta és kiirtotta a zsidókat, a szintiket és a romákat. Az NSZK unilaterális munkaerőtoborzási egyezményei [...], melyeket az elszegényedett mediterrán országok egy sorával kötöttek, egy olyan államilag irányított, a hazai

\footnotetext{
${ }^{43}$ A fogalmat a magyar müfordítás szóhasználatával szemben nem „kisebbségi”-ként, hanem az eredeti „kis” irodalom (littérature mineure) terminusra utalva használom. A koncepció kritikájához lásd Meyer véleményét: „A »kis irodalom« koncepciója korlátokba ütközik, hiszen a globalizáció korában egyre inkább átjárható a határ a domináns és a kisebbségi kultúra között. A centrum és periféria ellentétességére épülő fogalom nem képes megragadni a plurikulturalitás új formáit." Christine MEYer, Vorwort = Kosmopolitische „Germanophonie”, i. m., 17. A rizóma alakzatához ebben a kontextusban lásd ТномкA, i. m.

${ }^{44}$ Deleuze, Guattari, i. m., 33.

${ }^{45}$ Uo., 37.

${ }^{46} \mathrm{Uo}$.

${ }^{47}$ Többek között az alábbi munkákról van szó: Postkoloniale Germanistik: Bestandsaufnahme, theoretische Perspektiven, Lektüren, hg. Gabriele Dürbeck, Axel Dunker, Bielefeld, Aisthesis, 2014; Postkoloniale Schweiz: Formen und Folgen eines Kolonialismus ohne Kolonien, hg. Patricia Purtschert et al., Bielefeld, Transcript, 2012; Julian Osthues, Literatur als Palimpsest: Postkoloniale Ästhetik im deutschsprachigen Roman der Gegenwart, Bielefeld, Transcript, 2017; Spricht die Subalterne Deutsch? Migration und postkoloniale Kritik, hg. Hito Steyerl, Encarnación Gutiérrez RodríGuez, Münster, Unrast, 2003. A „posztkoloniális germanisztika” kritikájához lásd Adelson, The Turkish Turn, i. m., 176-177.

${ }^{48}$ Meyer, i. m., 6.
} 
munkaerőpiac igényeihez szabott bevándorlási folyamat kezdetét jelentették, amelyre a német lakosság a legkevésbé sem volt felkészítve. Ebben a kontextusban a nyugatnémet társadalom nem is alakíthatott ki elfogulatlan viszonyulást a „vendégmunkásaihoz”. [...] Az NSZK migrációs politikája ebben az értelemben a „belső kolonizáció” egyik formájának tekinthető, ahogyan azt Kien Nghi Ha kultúrakutató is megállapította. ${ }^{49}$

Ebben a kontextusban átgondolandó nem pusztán a nyelvek és kultúrák elválasztása és az erre építő köztesség pozíciója (melyet a német irodalomba „megérkezo”" Chamisso-szerzők kapcsán már bemutattunk), hanem a „németek” és a „bevándorlók” múltja, jelene és terei közötti elhatároló megkülönböztetés is. A migrációs mobilitás és a történelmi múltértelmezés egyidejü kihívásainak összefonódását Murat Aydemir és Alex Rotas, illetve Michael Rothberg azon elméleteinek és fogalmainak segítségével értelmezhetjük, amelyek nem csupán a posztmigráns kultúrák leírásához biztosítanak keretet, hanem érintkeznek az irodalmi interpretáció - például a diegetikus világ tér- és időaspektusaira irányuló elemzés - kategóriáival is.

\section{Helyek „,besüritése”, migrálás a múltba: a Chamisso-irodalom tere és ideje}

Ahogyan láthattuk, mind a Chamisso-irodalom, illetve a migráció kontextusában érintkező nyelvek és kultúrák kapcsolata, mind elméleti-értelmezői megközelítésük igencsak összetett és ambivalenciákkal terhelt. Ugyanez mondható el a múlthoz való viszonyulás által konstruálódó, „az etnikai hovatartozás nemzet-alapú értelmezésén” nyugvó német szubjektum és a "marginalizált és kisebbségi pozícióba szorított” ${ }^{50}$ migráns szubjektum közötti határvonásról. Michael Rothberg amerikai irodalomtörténész és holokausztkutató szerint az újraegyesítés utáni német társadalomban egymástól függetlenül zajlik a múltfeldolgozásra és a jelenkori migrációból adódó kérdésekre irányuló diszkusszió, ráadásul egy igen paradox konstellációban:

$\mathrm{Az}$ újraegyesített Németországban két uralkodó társadalmi logika szabályozza azt, hogy ki örökli a múltat, s hogy milyen jogok és felelősségek társulnak ehhez az örökséghez. Az egyik logika a német paradoxon, mely szerint a közelmúlt bűneivel kapcsolatos felelősségvállaláshoz, úgy tünik, szükséges fenntartani az etnikailag homogén német identitás képzetét még akkor is, ha ezeknek a bünöknek az egyik forrása maga az etnicitás ezen

\footnotetext{
${ }^{49}$ Uo., 13.

${ }^{50}$ Michael Rothberg, Multidirectional Memory in Migratory Settings: The Case of Post-Holocaust Germany = Transnational Memory: Circulation, Articulation, Scales, ed. Chiara De Cesari, Ann Rigney, Berlin - Boston, de Gruyter, 2014, 137.
} 
képzete volt. A másik pedig az úgynevezett migráns „dilemma”, melynek logikája szerint a migránsoknak azt mondják, hogy a holokauszt nem része a történelmüknek, mivel ők „etnikailag” nem németek, de ezzel egyidejüleg integrálhatatlannak bélyegzik őket a holokauszt-emlékezettel szembeni, vélt közömbösségükért. ${ }^{51}$

Németország napjainkban egyszerre posztmigratorikus és „holokauszt utáni” társadalom, ${ }^{52} \mathrm{~s}$ korántsem függetlenek egymástól (és összefonódásukban vizsgálandóak) a bevándorlás és a múltfeldolgozás folyamatai. Rothberg ezért Zafer Şenocak német-török író nyomában járva abból a retorikus kérdésből indul ki, hogy „a Németországba történő bevándorlás nem jelenti egyben a legfiatalabb német múltba történő bevándorlást is?" 53 Rothberg válasza, a transznacionális emlékezés etikájára építő többirányú emlékezet (multidirectional memory) ${ }^{54}$ koncepciója a már idézett két paradoxonból is kiutat biztosít. Rothberg a német identitást és általában magát az emlékezés dinamikáját is azáltal próbálja újradefiniálni és megragadni, hogy a demografikus változások (a migráció), a történelem és az emlékezet (illetve a nemzeti, a lokális és a transznacionális emlékezetrétegek) összefonódására és interakciójára fókuszál:

A bevándorlóknak a holokauszthoz és a nemzetiszocialista múlthoz való viszonyulásának hiánypótló kutatásával demonstrálható, hogy a német emlékezeti kultúrák megnyílhatnak a német identitás egy olyan újradefiniálásának irányába, amely számol a háborút követő időszak alapvető demográfiai átalakulásaival és transznacionális áramlataival egyaránt, anélkül, hogy kockára tenné a német felelősségvállalást a holokausztért. ${ }^{55}$

\footnotetext{
${ }^{51}$ Uo. (kiemelés az eredetiben)

${ }^{52}$ Uo., 142.

${ }_{53}$ Zafer ŞenocaK, Bülent Tulay, Deutschland: Eine Heimat für Türken = Zafer ŞEnocaK, Atlas des tropischen Deutschland: Essays, Berlin, Babel, 1993, 9-19, idézi RothberG, i. m., 124. A posztmigráns német emlékezeti kultúra ezen fontos aspektusát, a bevándorlók és a nemzetiszocialista német múlt feldolgozásának kapcsolatát számos szociológiai, illetve interdiszciplináris kutatás vizsgálja, például: Geschichte und Gedächtnis in der Einwanderungsgesellschaft: Migration zwischen historischer Rekonstruktion und Erinnerungspolitik, hg. Jan Motte, Rainer Ohliger, Essen, Klartext, 2004; Viola B. Georgi, Entliehene Erinnerung: Geschichtsbilder junger Migranten in Deutschland, Hamburg, Hamburger Edition HIS Verlag, 2003. Georgi empirikus felmérések alapján arra a következtetésre jut, hogy a fiatal migráns hátterủ németek számára a nemzetiszocializmus az az alapnarratíva, melynek fóliáján keresztül saját kirekesztésük, illetve inklúziós törekvéseik is elbeszélhetővé válnak.

${ }^{54}$ Rothberg ebben a vonatkozásban ismét Şenocakot idézi: „Itt az ideje összekötni a németeket foglalkoztató nemzetiszocialista múlt és a jelen kérdéseit. Nem azért, mintha a feldolgozás hatvan éve elegendő volna, hanem inkább azért, mert az emlékezésnek ma ismét olyan tapasztalattá kell válnia, amely túlmutatva a német Vergangenheitsbewältigung rituáléin eléri a fiatal embereket, és fontos ellenhatást biztosíthat az identitás romantizáló és archaikus elképzeléseivel szemben." Zafer ŞENOCAK, Das Land hinter den Buchstaben: Deutschland und der Islam im Umbruch, München, Babel, 2006, 144, idézi Rothberg, i. m., 124.

${ }^{55}$ Uo., 126.
} 
Az emlékezésnek a posztmigratórikus társadalmakra jellemző többirányúsága a migráció és az emlékezés elhelyez(ked)ésének (locatedness) változásaiban nyilvánul meg. Rothberg többek között azt a projektet veszi górcső alá, amelynek keretében berlinneuköllni, elsősorban török vagy arab anyanyelvü bevándorló nők vállalkoztak a nemzetiszocialista múlt megismerésére (Projekt „Neuköllner Stadtteilmütter”, 2006) és arra a következtetésre jut, hogy a migratórikus helyszíneken (migratory settings ${ }^{56}$ ) a német emlékezeti kultúra transznacionális és transzkulturális dimenziói annak „besürüsödésében" (thickening) érhetőek tetten. Rothberg Aydemir és Rotas fogalmát idézi, amellyel a szerzőpáros a mozgás és az elhelyezkedés mozzanatainak látszólagos ellentmondását felülírva beszél a kulturális helyszínek (settings) többirányú „besürüsödéséről” a migráció kontextusában:

A címünkben [Migratory settings] olvasható szókombináció [...] egy perspektívaváltásra utal a migráció értelmezésében, a helytől helyig tartó mozgás képzetétől a helyen belül zajló mozgás irányába. A migráció nem csupán helyek között történik, de kihatással is van helyben, a helyre. Azt javasoljuk röviden, hogy a migráció tekintetében a tér tárgyiasitása vagy transzcendentálása helyett sokkal inkább annak „sürüsödéséről” (thickened) beszéljünk, hiszen a hely sokféle emlék, képzelet, álom, fantázia, rémálom, elvárás és idealizáció helyszínévé válik, melyet a migráció tapasztalatai - mind a bevándorlók, mind a lakosság tapasztalatai - kapcsolnak össze egymással. A migráció teljességgel determinálja, eltérő történetek mise-en-scéne-évé változtatja a helyet. ${ }^{57}$

Rothberg vizsgálódásai elsősorban a történelmi múlt elbeszéléseinek összefonódásaira irányulnak, s ezeket illusztrálandó megemlíti például Şenocak Gefährliche Verwandtschaft (Veszélyes rokonság, 1998) című nagysikerű családregényét, mely a német, török és zsidó történelem (a holokauszt és az örmény népirtás feldolgozásához kötődő problematikák) kapcsolódásait tematizálja. Az irodalmi szövegek előtérbe kerülnek viszont Aydemir és Rotas megközelítésében, akik a Mieke Bal által kidolgozott vándorló fogalmak és migratórikus esztétika koncepcióiból kiindulva, kifejezetten a tér „besűrűsödésének” esztétikai dimenzióira fókuszálnak, vagyis „a migrációs folyamatok esztétikai dimenziójának és az esztétikai folyamatok migratórikus dimenziójának kölcsönhatásait" vizsgálják. ${ }^{58}$ Ismét a dichotómikus elválasztások meghaladására látunk tehát példát: egyfelől térbeli értelemben (a migráció nem két hely közötti, hanem egy helyen belüli mozgás), másrészt idő- és térbeli folyamatok: az emlékezet, illetve történelem („múlt”) és a migráció („,jelen”) kutatásának kontextusában („német

\footnotetext{
${ }^{56}$ Rothberg Aydemir és Rotas fogalmát használja: Murat Aydemir, Alex Rotas, Migratory Settings, Thamyris/Intersecting, 2008/19, 7-32.

${ }^{57}$ Uo., 7.

${ }^{58}$ Uo., 8.
} 
paradoxon”, „migráns »dilemma«"), harmadrészt a statikusság (implacement) és a mozgás (migráció) ellentételezésének vagy a „»reális" politikai, társadalmi és gazdasági” és a "fiktív, színre vitt, elképzelt, észlelt vagy esztétikai" ${ }^{59}$ jelenségek megkülönböztetésére vonatkozóan. A migráció ezen átjárhatóságok kontextusában olyan folyamatok jelölője, melyek a posztmigráns emlékezeti kultúrák „sűrü” terét és idejét hozzák létre, kutatása tehát eleve és szükségszerüen a migráció esztétikájának vizsgálatát jelenti, amely analóg az irodalmiságot konstituáló nyelvi-imaginatív „sürűség” értelmezésével:

\begin{abstract}
A migratórikus helyszínek (migratory settings) [...] azon történetek (histories) és jövők térbeli szimultaneitását jelölik, melyeknek emlékezetében, létrehozásában és elképzelésében bevándorlók és a bennszülöttek különböző csoportjai érintettek. A bevándorlók előzetes elvárásai az új élethelyükre vonatkozóan, akárcsak a régi helyükhöz kötődő retrospektív emlékeik, aktív részévé válnak új környezetüknek, melyen a többi lakossal osztoznak. [...] Ezen emlékek valójában olyan kulturális identifikációkat létrehozó „imaginatív aktusok”, melyek nem redukálhatóak a két hely egyikére sem. Ezek az aktívan elképzelt és újra elképzelt emlékek ugyanakkor részévé válnak annak a helynek, ahol történnek, amit gazdagítanak és átalakítanak. ${ }^{60}$
\end{abstract}

A Rothberg, Aydemir és Rotas által kidolgozott fogalmi-elméleti keret így nem pusztán az emlékezeti kultúra és a történelempolitika szempontjából releváns kérdések kontextusában nyer heurisztikai jelentőséget, mint például a transznacionális európai emlékezeti közösséget konstruáló versengő áldozati diskurzusok problematizálásában, ${ }^{61}$ hanem irodalmi szövegek „migratórikus esztétikájának” elemzésében is.

\footnotetext{
${ }^{59}$ Uo., 7.

${ }^{60}$ Uo., 20.

${ }^{61}$ Rothberg Assmann dialogikus emlékezet koncepciójához hasonlóan nem pusztán bizonyos emlékezetek határokon és generációkon átívelő összefonódására, vagyis a történelmi múlt többszólamú, változó és plurális emlékezési aktusokból összetevődő dinamikus konstrukciós folyamatára koncentrál, hanem olyan konkrét és politikailag is releváns kérdésekhez köti a transzkulturális „mnemográfia” elméleti belátásait, mint a történelmi erőszaktapasztalatok (a gyarmatosítás vagy a holokauszt) feldolgozása. Rothberg úgy köti össze a náci népirtás és a kolonizáció történelmi traumájának emlékezetét, hogy nem lépteti őket versenybe egymással, hanem kapcsolódási pontjaikra koncentrál: felmutatja például, hogyan segítheti a holokausztemlékezet kerete és nyelve más traumatikus tapasztalatok artikulációját anélkül, hogy mindez relativizálná a holokauszt szingularitásának tézisét. Assmann a német áldozatnarratívák kapcsán hasonlóan traumaparadigmának nevezi a holokausztot, illetve a Gulág és a holokauszt örökségének transznacionális európai emlékezetté történő átformálódásáról beszél. Ennek a feltétele a két traumatikus tapasztalat egymást kiegészítő viszonyának elismerése, amely a sztálini és a náci terror áldozatainak versenybe léptetését (Opferkonkurrenz) váltja fel. Assmann Bernd Faulenbach tézisét idézi, miszerint a sztálinizmus emlékezete nem relativizálhatja a holokauszt emlékezetét, a holokausztemlékezet viszont nem trivializálhatja a sztálini terror emlékezetét. Aleida Assmann, Transnational Memories, European Review, 2014/4, 546-556, föként 552.
} 
Leslie A. Adelson a kortárs német nyelvü irodalom „török fordulatát” tárgyaló munkáiban ${ }^{62}$ például Rothberghez hasonlóan a migrációhoz köthető és az emlékezetkultúra szemszögéböl is releváns mozzanatokat vonatkoztat egymásra, a történelem/emlékezés, a migráció és az irodalom összefonódásait elemzi - akárcsak a viktimizáció és a genocídium kontextusában összekapcsolódó német, török és zsidó érintkező történetek (touching tales) esetében. A „török fordulat” (türkishe Wende, Turkish turn) kifejezés nem a török származású szerzők műveinek térhódítására utal, hanem a rendszerváltás vonatkozásában elterjedt „,fordulat irodalma” (Wendeliteratur, ,a rendszerváltás irodalma") fogalomhoz hasonlóan a történelmi folyamatok és az esztétikai reflexió kapcsolatát jelöli. Adelson szerint a „török hátterü” német nyelvü szövegek a „hagyományos értelemben vett” Wende-irodalomhoz hasonlóan „a nemzeti újraegyesítés kulturális kihatásaira való reflexió" területei, összekötődnek tehát a „belső német kettéosztottságból eredő kelet-nyugat koordináták" azokkal a kelet-nyugat koordinátákkal, amelyek egy vélt orientális (török) jelenlét és egy vélt okcidentális Németország egymásra vetítéséből adódnak. ${ }^{63}$

Adelson a kortárs német nyelvü irodalmat tehát a „kelet-nyugat koordináták” jelentés-eltolódásainak horizontjából vizsgálja, a rendszerváltás, a történelmi múltfeldolgozás és a török bevándorlás kérdéseinek kapcsán érintkező narratívákat tár fel. Ezt, a német emlékezeti kultúrát kétségkívül döntően meghatározó konstellációt mindazonáltal ki kell egészítenünk a kelet-európai migráció jelenségével, ${ }^{64}$ amely hasonló erővel bír már a rendszerváltozás és az Európai Unió keleti bővítése előtti időszakban is. A német, zsidó és török touching tales hármasa mellett ebben a kontextusban is figyelmet érdemelnek az egykori vasfüggöny mögötti országok olyan traumatikus történelmi tapasztalatai, mint a Gulág, az 56-os forradalom, a rendszerváltás vagy a balkáni háborúk, melyeknek az egyesült Európa kulturális emlékezetében „kötelezően” betöltött szerepe jó ideje számos kutatás visszatérő témája, elsősorban a holokauszt-emlékezettel és a dialogikus-transznacionális emlékezeti közösségek kialakulásával összefüggésben. ${ }^{65}$

\footnotetext{
${ }^{62}$ Leslie A. Adelson, Die "türkische Wende” in der deutschsprachigen Gegenwartsliteratur = Die andere deutsche Literatur, i. m., 53-59; AdELson, The Turkish..., i. m.

${ }^{63}$ Adelson, Die ,türkische Wende”, i. m., 53.

${ }^{64}$ A kelet- és közép-európai szerzők német nyelvű irodalmához lásd Brigid HaInes, German-language Writing from Eastern and Central Europe = Contemporary German Fiction: Writing in the Berlin Republic, ed. Stuart Taberner, New York, Cambridge University Press, 2007, 215-229. - A „kelet-európai emlékezet" fogalmához lásd Margrit ZINGgeler, The "Eastern European Memory" in Contemporary German Swiss Literature, GLOSSEN: German Literature and Culture after 1945, 2015/40. http://blogs.dickinson. edu/glossen/most-recent-issue-glossen-402015/margrit-zinggeler-glossen40-2015/ (Letöltés ideje: 2018. február 1.). - A Kelet- és Nyugat- illetve Közép-Európa (mint emlékezethelyek) közötti határvonáshoz lásd Jacques Le Rider, Mitteleuropa as a lieu de mémoire = Cultural Memory Studies: An International and Interdisciplinary Handbook, ed. Astrid ErLL, Ansgar NüNNING, Berlin, Walter de Gruyter, 2008, 37-46.

${ }^{65}$ A transznacionális emlékezet kategóriája elsőként a holokausztemlékezet dekontextualizálódásával kapcsolatban merült fel. A civilizációs törés (Dan Diner) közös és elkötelező érvényü emlékként való intézményesülését a Task Force for International Cooperation on Holocaust Education, Remembrance and Research (a mai IHRA, azaz International Holocaust Remembrance Alliance) 1998-as megalapítása, illetve
} 
Bár a kelet-európai hátterű szerzők német nyelvű „posztkommunista irodalma” egyelöre még korántsem kapott akkora figyelmet a germanisztikai kutatásokban, mint az egyébként hasonlóan pozicionálható német-török vagy a keletnémet irodalom, okkal beszélnek mégis a "török fordulathoz” hasonlóan a kortárs német irodalom „balkáni” vagy „jugoszláv fordulatáról” (Yugoslavian/Balcan turn ${ }^{66}$ ) „,keleteurópai fordulatáról” (eastern turn ${ }^{67}$ ) vagy „keleti bővítéséről” (Osterweiterung ${ }^{68}$ ) is. A „fordulatok” immáron egyre inkább inflálódni látszó fogalmiságán túlmutatóan a transznacionalizmus poétikájának van döntö szerepe a német nyelvü „kelet-európai" irodalom jelentőségének felmutatásában, illetve az egyszólamú, monologikus nemzeti emlékezetkonstrukciókat felváltó vagy kiegészítő dialogikus, európai emlékezetkultúra (Assmann) ${ }^{69}$ problematizálásában is. A posztmigráns társadalmak

a Stockholm International Forum on the Holocaust nyilatkozatai fémjelzik (Assmann, i. m., 549). A holokauszt univerzalizálódott, vagyis áthelyeződött a lokális vagy nemzeti múltból, és egyfajta transznacionális emlékezeti közösség közös traumatikus tapasztalataként vált Európa „negatív alapítómítoszává”. (Claus LEGGEwIE, Gleichermaßen verbrecherisch? Totalitäre Erfahrung und europäische Erinnerung, 2006, www. eurozine.com/articles/2006-12-20-leggewie-de.html, Henry Rousso, Das Dilemma eines europäischen Gedächtnisses, Zeithistorische Forschungen, 2004/3. http://www.zeithistorische-forschungen.de/3-2004/ id\%3D4663 (Letöltés ideje: 2016. február 1.). Ugyanekkor éppen ebben a kontextusban számos törésvonal is láthatóvá vált az egységesülő Európa emlékezeti kultúráján belül. Nem pusztán a második világháborús múltfeldolgozással kapcsolatban figyelhető meg ugyanis egyfajta aszimmetria a nyugat-európai demokráciák és a posztkommunista emlékezeti közösségek között: ez egyébként Assmann szerint abban nyilvánul meg, hogy a kelet-európai nemzetekre elsősorban - bár nem kizárólagosan - a tettes-emlékezet megszilárdulását, a saját bünök áldozataival érzett empátiát, a transznacionális emlékezetkultúra dialogikusságát megakadályozó önviktimizáció a jellemzö. (Aleida Assmann, Das neue Unbehagen an der Erinnerungskultur: Eine Intervention, München, Beck, 2013, 142-180.) Szembetűnő apóriája ezen túlmenően az alakulófélben lévő európai emlékezetkultúrának a történelmi erőszaktapasztalatok, a diktatórikus múlttal való szembenézés eltérő hangsúlya, problematikus aránytalansága a kelet-európai és a nyugati társadalmakban. Leggewie Assmannhoz hasonlóan azzal érvel, hogy Kelet-Európában a holokauszt emlékezete „hideg”, a szovjet megszállásé pedig „forró”, míg Nyugat-Európában fordítva, a nemzetiszocialista népirtás történelmi tapasztalata általában identitás-konstitutív („forró”), a kommunista diktatúra bűneinek emléke pedig marginális („hideg”). (LeGGEWIE, i. m.)

${ }^{66}$ Boris Previšić, Poetik der Marginalität: Balcanturn gefällig? = Von der nationalen zur internationalen Literatur: Transkulturelle deutschsprachige Literatur und Kultur im Zeitalter globaler Migration, hg. Helmut Schmitz, Amsterdam, New York, rodopi, 2009, 187-203.

${ }^{67}$ Brigid Haines, Introduction: The Eastern European Turn in Contemporary German-Language Literature, German Life and Letters, 2015/2, 145-153; Uö, The Eastern Turn in Contemporary German, Swiss and Austrian Literature, Debatte: Journal of Contemporary Central and Eastern Europe, 2008/2, 135-149.

${ }^{68}$ Irmgard Ackermann, Die Osterweiterung in der deutschsprachigen „Migrantenliteratur" vor und nach der Wende = Eine Sprache, viele Horizonte: die Osterweiterung der deutschsprachigen Literatur; Porträts einer neuen europäischen Generation, hg. Michaela Bürger-KofTIS, Wien, Praesens, 2008, 13-22; Leonhard Hermann, Silke Horstкотte, Gegenwartsliteratur: Eine Einführung, Stuttgart, Metzler, 2016, 128.

${ }^{69}$ A dialogikus európai emlékezés szemben a monologikus nemzeti emlékezéssel Assmann értelmezésében nem pusztán a saját szenvedésre (vagy a dicsőséges múltra) fókuszál, hanem elismeri a tettességet is, és empatikusan együtt érez a saját történelmi bünöknek áldozatul esett szenvedőkkel is 
kulturális emlékezetére irányuló, irodalom- vagy történettudományi vonatkozású vizsgálódásokban néhány évtizede konjunktúrának örvend a transznacionális kérdéshorizont (melybe könnyedén integrálhatóak a transzlokalitás kategóriájával megragadható belátások és a transzkulturalizmus terminológiájával leírható jelenségek is, így a kulturális és társadalmi terek pluralizálódása és folyamatos mozgása, vagy ettől elválaszthatatlanul a nyelvi és politikai formációk, jelentések fragmentalizálódása, a jelek, szövegek és emberek térben és időben globális cirkulációja). A memory studies a transznacionalitás elméletének keretében immáron transzlokális összefonódások: dinamikusan változó emlékezeti terek „utazó” emlékeinek vizsgálatára vállalkozik az emlékezetkutatás „harmadik hullámának”70 jellegzetes elemzési kategóriái olyan új fogalmak, mint a mémoire croisée vagy az entangled memory („összefonódó emlékezetek”), a travelling memory („utazó emlékezet”), vagy a már említett multidirectional memory („többirányú emlékezet”). A Kelet-és Nyugat-Európa közötti „határátlépo” szövegek relevanciája félreismerhetetlen a nemzeti és európai múltértelmezési minták, valamint a kollektív emlékezetet konstruáló monologikus és dialogikus struktúrák összefonódásainak kontextusában: értelmezésük az irodalmi szövegelemzésen túlmutatóan problematizálja ugyanis a kelet-európai történelem és kultúra emlékezetének helyét a német nyelvü, illetve a dialogikus európai emlékezeti kultúrákban. Ennek ellenére csupán elvétve találunk olyan megközelítéseket (Bürger-Koftis 2008, Cornejo et al. 2014, ${ }^{71}$ Zinggeller 2015), melyek a hagyományos komparatisztika fogalmiságán túllépve, a határátlépés transznacionális esztétikájának fényében vizsgálnák a német irodalom „keleti bővítésének” problematikáját.

(Aleida Assmann, Auf dem Weg zu einer europäischen Gedächtniskultur?, Wien, Picus, 2012, 58-59). A transznacionális esztétika és a posztkolonializmus, illetve posztstrukturalizmus összefüggéseihez, illetve az irodalomtudomány „transznacionális fordulatához” lásd az alábbi munkákat: Paul JAY, Global Matters: The Transnational Turn in Literary Studies, New York, Cornell University Press, 2010; Stuart TABERner, Transnationalism and German Language Literature in the Twenty-First Century, Cham, Palgrave Macmillan, 2017; JABLONCZAY Tímea, Transznacionalizmus a gyakorlatban: migrációs praxisok a könyvek, az írásmódok, a müfajok és a forditási stratégiák geográfiájában, Helikon, 2015/2, 137-156.

${ }^{70}$ Az emlékezetelméletek „harmadik hullámához”, illetve a kollektív emlékezet vizsgálatának Wulf Kansteiner és Astrid Erll általi kritikájához lásd Gregor FeIndT et al., Entangled Memory: Toward a Third Wave in Memory Studies, History and Theory, 2014/1, 24-44. - Az emlékezethelyek (lieux de mémoire) kutatásának Pierre Nora nevéhez kötődő koncepcióját meglehetősen korán (Pim den Boer) és többen bírálták azért, amiért nemzetállami keretbe helyezi az emlékezés vizsgálatát (Csáky Moritz koncepciója ezzel szembehelyezkedve kifejezetten többértelmű szövegként vagy nyelvként dekódolja és dekonstruálja az emlékezethelyek „szövetét”, vö. Moritz CsÁкY, Die Mehrdeutigkeit von Gedächtnis und Erinnerung: Die Mehrdeutigkeit von Gedächtnis und Erinnerung: Ein kritischer Beitrag zur historischen Gedächtnisforschung, 2004. https://www.vifaost.de/texte-materialien/digitale-reihen-und- sammlungen/ handbuch /handb-mehrdeutigk/ (Letöltés ideje: 2018. február 1.) Astrid Erll, Michael Werner és Benedicte Zimmermann kategóriáihoz lásd Astrid ErLl, Travelling Memory, Parallax, 2011/4 (Special Issue Transcultural Memory), 4-18; Michael Werner, Benedicte Zimmermann, Beyond Comparison: Histoire Croisée and the Challenge of Reflexivity, History and Theory, 2006/1, 30-50.

${ }^{71}$ Wie viele Sprachen spricht die Literatur? Deutschsprachige Gegenwartsliteratur aus Mittel- und Osteuropa, hg. Renata Cornejo et al., Wien, Praesens, 2014. 


\section{A Chamisso-irodalom keleti fordulata? Magyar származású szerzők német nyelvü irodalma a transznacionális emlékezetkutatás kontextusában}

A posztmigratórikus német emlékezeti kultúra érintkező történeteinek (touching tales), többirányú emlékeinek (multidirectional memories) és „sürü” migratórikus helyszíneinek (thickened places, migratory settings) bemutatott elméleti reflexiója korántsem értelmezhető egyfajta legitimációs háttérként a többnyelvű vagy bevándorló szerzők irodalmának tematikus vagy biografikus olvasatához. Sokkal inkább olyan fogalmisággal állunk szemben, amely termékeny belátásokhoz vezet a nyelv és a történelem (történetek) deterritorializálódására irányuló migratórikus esztétika kontextusában, így az esztétikai és a migrációhoz kötődő idegenség-tapasztalatok, dialogicitás és „sűrűség” strukturális analógiáinak megvilágításában. Nem pusztán a szövegek tematikus szintjén mutatható fel például a múltfeldolgozással kapcsolatban megfigyelhető aszimmetria visszhangja a nyugat-európai demokráciák és a posztkommunista emlékezeti közösségek között, hanem egymásra vonatkoztathatóak a posztmigráns tér „sűrüségének” és az emlékezés struktúráinak többszólamúsága, a kulturális identitások pluralitása és a polifón irodalmi szöveg dialogicitása is. A német irodalom „keleti bővítésével” kapcsolatos diszkussziót egyelöre viszont még hasonló ellentmondások jellemzik, mint a Chamisso-irodalomra vonatkozót, így például a nyelviség mint (esztétikai) kritérium és a nyelv-, illetve kultúraváltás mint tematikus/életrajzi kritérium közötti feszültség, vagy az ambivalencia egy kategória és szövegkorpusz létrehozása és a homogenizálás, illetve a kategorizálás egyidejü elutasítása között.

A német nyelvterületeken körülbelül az ezredforduló óta különösen keresettek és elismertek, sőt talán a leggyakrabban díjazottak néhány német (anya)nyelven író, de magyarországi származású írónő kötetei: az Ingeborg Bachmann-díjat 1999-ben elnyert Terézia Mora munkái, a 2010-ben a német és svájci könyvdíjjal (Deutscher Buchpreis, Schweizer Buchpreis) kitüntetett Melinda Nadj Abonji prózája (Galambok röppennek föl), Zsuzsa Bánk négy prominens (német) díjjal is jutalmazott $A z$ úszó (Der Schwimmer, 2002) című regénye - de ugyanebbe a kategóriába sorolhatnánk Ilma Rakusa vagy Zsuzsanna Gahse németül megjelent és magyar müfordításban is olvasható szövegeit is. ${ }^{72}$ A Chamisso-díjjal kitüntetett szerzők között feltűnően nagy számban

\footnotetext{
${ }^{72}$ Terézia Mora nem csupán Esterházy Péter, Örkény István és Parti Nagy Lajos műveinek fordítójaként tett szert hírnévre, hanem prózai műveivel is - magyar műfordításban a Magvető Kiadó gondozásában jelent meg közülük a Különös anyag címü elbeszélésgyüjtemény (2001 [1999]), illetve a Nap mint nap (2006 [2004]), Az egyetlen ember a kontinensen (2011 [2009]) és A szörnyeteg (2014 [2013]) címü regények. Ilma Rakusa Rengeteg tenger című müve 2011-ben jelent meg magyarul. Zsuzsanna Gahse szintén Esterházy, illetve többek között Nádas Péter, Mészöly Miklós és Rakovszky Zsuzsa szövegeit fordította németre, de több mint huszonöt saját kötetet is magáénak tudhat: magyarul olvasható például az Átültetve (1993) és a Duna-kockák (2010). A modern és kortárs magyar irodalom (Kosztolányi Dezső, Márai Sándor, Szerb Antal, Nádas Péter és Kertész Imre) német fordítójaként ismertté vált Christina Virágh szintén önálló köteteket is jegyez. A német nyelvterületen alkotó, magyar származású írók listája nem lenne teljes Ágota Kristóf neve
} 
találunk magyar származásúakat (Csiba László és Dalos György 1995, Terézia Mora 1999, Ilma Rakusa 2003, Zsuzsa Bánk 2004, Zsuzsanna Gahse 2006, Léda Forgó 2008, Ákos Doma 2010), René Kegelmann ennek alapján egy „részkanonizációt” konstatál a kortárs német nyelvü irodalmon belül. ${ }^{73}$

Kegelmann a magyar származású szerzők irodalmának korpuszát a többnyelvüség és többkultúrájúság (osztrák-magyar) „hagyományára” hivatkozva határolja el a „török, görög vagy olasz vendégmunkás- és migráns irodalom"-tól, majd megállapítja, hogy mégsem kezelhetőek „csoportjelenségként” az érintett szerzők..$^{74}$ A Chamisso-dij alapításakor Harald Weinrichhel szorosan együttmüködő germanista, Irmgard Ackermann volt az első, aki a Chamisso-dij „keleti bővítéséről” beszélt, sőt ezt illusztrálandó össze is állított egy kánont, a releváns szerzők és műveket számba vevő „bio-bibliografikus” leltár formájában. ${ }^{75}$ Ackermann egyrészt leírja a „keleti bővítés” új irodalmi tendenciáját: „Kelet- és délkelet-európai szerzők vándorolnak be a német nyelvű irodalomba, azáltal, hogy a német nyelvet teszik irodalmi kreativitásuk médiumává" ${ }^{76}$ Másrészt megállapítja azt is, hogy „ez az irodalmi keleti bővítés nemcsak a politikai keleti bővítéssel kezdődött, hanem egy jóval tágabb időszakot fog át, és így időben nem rögzíthető egyértelműen", ${ }^{77}$ majd a „fiatalabb keleti szerzők” fellépésének prefigurációjaként a német-cseh prágai kultúrát elemzi. A „keleti fordulat” (eastern turn) fogalmát kidolgozó Brigid Haines szintén a kelet-európai származású szerzők különösen nagy létszámából indul ki, majd műveik alapján összeállítja a szóban forgó irodalom jellegzetességeinek egy olyan „katalógusát”, melynek provizorikusságára és általánosító jellegére Haines kezdettől fogva reflektál.

Öt közös tulajdonságot sorol fel a kelet-európai hátterü irodalom formájára, tartalmára vagy recepciójára vonatkozóan: a szövegek „közös nevezője” eszerint a „kommunista uralom megélt valósága [...]; a nyugati irányba történő migráció elidegenítő tapasztalata; az általános csalódottság az életben a korai 1990-es években [...]; az egykori Jugoszlávia területén zajló sokkoló konfliktusok [...] és az élet dezorientációja napjaink hidegháború utáni Európájában"78 Jellemző ezen kívül a népszerü prózai forma dominanciája és egyfajta felvilágosító, illetve megfelelési szándék az ismeretlen Kelet-Európát felfedezni vágyó nyugati közönség igényeivel szemben. Haines ugyanakkor azt is megállapítja, hogy a szóban forgó irodalom ellenáll a restriktív, kollektív megnevezésnek, és nem kezelhető közös korpuszként sem nyelvi, sem történelmi-tematikus szempontok alapján:

nélkül - a többszörösen díjazott szerzőnő irodalmi alkotásait, így többek között A nagy füzet (1989 [1986]) címü regényt francia nyelven írta.

${ }^{73}$ Kegelmann, i. m., 13.

${ }^{74}$ Uo., 24.

${ }^{75}$ ACKermann, Die Osterweiterung, i. m.,18; Irmgard ACKermann, Bio-bibliographischer Anhang: Autoren aus Ost- und Südosteuropa in der deutschsprachigen Gegenwartsliteratur = Eine Sprache, viele Horizonte, $i$. m., 23-38.

${ }^{76}$ Ackermann, Die Osterweiterung, i. m., 13.

${ }^{77}$ Uo., 13-14.

${ }^{78}$ Haines, The Eastern Turn, i. m., 139. 
A német nyelvű prózairodalom ezen új korpusza ideiglenesen egységesíthető, mivel [...] a keleti blokk kommunista időszakát, s annak kihatásait tematizálja. Minden más tekintetben viszont [...] ellenállnak ezek a szövegek annak, hogy behatároljuk őket, és kollektív módon bánjunk velük, hiszen valójában egybeesnek, és termékeny kölcsönhatásban állnak a német nyelvű vagy más kortárs irodalommal. ${ }^{79}$

Ismételten azt látjuk tehát, hogy egy újfajta fogalmiság („keleti fordulat”) elméleti koncepcionalizálásában felbomlik a nemzeti irodalmak és az ettől eltérő irodalmak hierarchiájának kizáró logikája. Ugyanakkor az új kategóriák sem egyértelműek, sőt szükségtelennek is bizonyulhatnak - ahogyan ez történt például az „idegen”-„,saját”, „anyanyelv”-,idegen nyelv” közötti elválasztások esetében is, melyek meghaladása egy végeredményben általános jelenség (az írás idegensége) jegyében történt. Haines ebben a kontextusban az alábbiakat állapítja meg:

A kelet-európai fordulat (Eastern European turn) nem pusztán újonnan bevándorló szerzők egy hullámára vonatkozik, bár létezett egy ilyen óriási hatású hullám, hanem egy fogalmi számvetést is jelöl a kortárs, a fordulat utáni Európával, számos szemszögből. Itt az ideje [...], hogy elbúcsúzzunk a nyelvi és nemzeti önazonosságoktól, a különálló kultúrák azon koncepciójától, mely az „interkulturális germanisztika” fogalmában is benne rejlik, s helyette az írás transznacionális és porózus jellegéről beszéljünk. ${ }^{80}$

Termékeny párbeszédbe léptethetők tehát az identitás és alteritás vonatkozásában további kulturális és esztétikai jelenségek is, mint például az emlékezet többértelmüsége, sokszoros kódoltsága és az irodalmi szövegek polifóniája, az európai emlékezeti kultúra említett dialogikussága (Assmann) és az irodalom inherens dialogicitása (Bahtyin). A transznacionális emlékezeti közösségek és a posztmigrációs társadalmak kutatásának említett újabb tendenciái ugyanis, ahogyan láthattuk, esztétikai-filozófia kérdéshorizontokkal is összefüggenek, az irodalmi interpretáció fogalmi keretéül is szolgálhatnak, és egyben hozzájárulhatnak hagyományos filozófiai, hermeneutikai vagy esztétikai fogalmak (idegenség, fordítás, dialogicitás) újraértelmezéséhez is. A határátlépés például nem pusztán egy-egy migrációs történet, egy interkulturális perspektívájú családregény szereplőinek életrajzi tapasztalata, hanem alapvető konstrukciós mechanizmusa a mindenkori identitásnak: így a nyelvek és kultúrák között vándorló migráns élettörténete, a kettős (többszörös) identitások jelensége az elbeszélés és az identitáskonstrukció alapvetö összefüggéseire irányítja a figyelmet. Sőt, maga az irodalmi tevékenység, az írás is feltételez egyfajta határátlépést: a megszokottól, a

\footnotetext{
${ }^{79}$ Uo., 137-138.

${ }^{80}$ Haines, Introduction, i. m., 147.
} 
sajáttól való eltérést, elidegenedést (s ezt vonatkoztathatjuk akár az irodalmi nyelvre, akár az írói szubjektumra).

$\mathrm{Az}$ irodalmi szöveg tehát egy határátlépés eredménye: nem pusztán azért, mert lehetővé tesz az olvasó számára egyfajta identitásváltozást, hanem mert maga a szöveg is távoli, idegen, elidegenítés által konstruált. A tágabb értelemben vett migrációs tapasztalatot cselekményesítő szövegek vizsgálata tehát túl azon, hogy a saját kultúra és a bevándorlók (kelet-európai) történelmének, történeteinek a viszonyára irányul, arra is lehetőséget kínál, hogy a kollektív emlékezetet a monologikus struktúrák felől a dialogikus irányába mozdítsa el. Annál inkább meglepő ezért, hogy a már felsorolt németül író magyar származású írónők jellegzetesen „kelet-európai” történeteket - az 56-os forradalmat (Bánk), a diktatúrák erőszaktapasztalatait (Mora), a jugoszláv háborúkat (Nadj Abonji) - is tematizáló regényeinek bár jelentős visszhangja van a germanisztikában, életmüvük fogadtatása a hazai tudományosságban még mindig részleges. Kegelmann még az 1999-es Frankfurti Könyvvásár apropóján - Kukorelly Endre szavait idézve - azt állapítja meg, hogy Magyarországot a németországi közönség felé képviselő szerzők olyannyira ismeretlenek hazánkban, mintha nem is történt volna rendszerváltás, ${ }^{81} \mathrm{~s}$ ez a vélemény a müfordítások növekvő számának ellenére sem veszített érvényéből. A Chamisso-díj történetének lezáródásával párhuzamosan, (amint annak kontextusában is) folyamatosan megkérdőjeleződtek ugyan elméleti megközelítések és fogalmiságok - ahhoz mégsem férhet kétség, hogy a „Chamisso-irodalom” értelmezése továbbra is ígéretes perspektívákat rejt mind a germanisztika és az irodalomtudomány, mind a posztmigratórikus társadalmakra és a transznacionális emlékezeti közösségekre irányuló interdiszciplináris kutatások távlatából.

\section{Eszter Pabis}

"After the Chamisso Prize, Beyond the "Chamisso Literature" Contemporary German-language Literature in the Context of Migration

The Adelbert von Chamisso Prize was (up to 2017) awarded by the Robert Bosch Stiftung to honour German-language authors whose works are shaped by a change of culture and an unusual way of using the language. The present article explores the development of the "Chamisso literature" (into which "migrant literature" evolved), its place in literary history and the recent trends it reflects. It also intends to provide an overview of theoretical approaches to the connection between literature, migration and German memory cultures, with special emphasis on the so called "eastern turn" in German literature.

\footnotetext{
${ }^{81}$ René Kegelmann, Transfer und Rücktransfer: Überlegungen zu Terézia Moras Erzählband Seltsame Materie in Deutschland und dessen ungarischen Übersetzung Különös anyag, Trans, 2010/17. http:// www.inst.at/trans/17Nr/2-5/2-5_kegelmann17.htm (Letöltés ideje: 2018. február 1.)
} 